\title{
MODELLING OF RSG-GAS HEAT EXCHANGER FOR STEADY-STATE SIMULATION
}

\author{
Andi S. Ekariansyah \\ Pusat Teknologi dan Keselamatan Reaktor Nuklir - BATAN
}

\begin{abstract}
MODELLING OF RSG-GAS HEAT EXCHANGER FOR STEADY-STATE SIMULATION. The multipurposes reactor G.A Siwabessy (RSG-GAS) is a open pool, water cooled reactor with plate type fuel elements having thermal power of $30 \mathrm{MWt}$. Its design has been a subject for research in term of its safety against postulated design basis accident. For the purpose of safety analysis, its complete design have been modelled using various thermalhydraulic code, which has to be validated for the steady-state condition. The model generated so far did not include the model of the heat exchanger as it is designed and described in the RSG-GAS design specification. Therefore the purpose of this research is to obtain a heat exchanger model as realistic as possible using the RELAP5/ SCDAP/Mod3.4 code. From the generated model, the performace of the heat exchanger design will be evaluated to analyze its effect on the steady-state simulation during RSG-GAS full power. The simulation results show that the performance of the obtained heat exchanger model has been validated with the design specifications to remove the core heat during the full power simulation. On that condition, the inlet secondary temperature and loss coefficient plays important role in taking the inlet and outlet primary temperature to be close with the experimental data and other RSG-GAS model.
\end{abstract}

Keywords: RSG-GAS, heat exchanger model, RELAP5, steady state simulation, performance

\section{ABSTRAK}

PEMODELAN PENUKAR KALOR REAKTOR RSG-GAS UNTUK SIMULASI KONDISI TUNAK. Reaktor Serba Guna G.A Siwabessy (RSG-GAS) adalah reaktor penlitian tipe kolam terbuka dan berpendingin air ringan dengan elemen bahan bakar tipe pelat untuk membangkitkan daya 30 MWt. Desain reaktornya telah menjadi subjek penelitian dalam hal aspek keselamatan terhadap kecelakaan dasar desain terpostulasi. Untuk tujuan analisis keselamatan, desainnya secara lengkap telah dimodelkan menggunakan beberapa jenis program perhitungan termalhydraulik yang harus divalidasi untuk kondisi tunak. Model RSG-GAS yang telah dikembangkan selama ini belum mencakup model penukar panas sesuai desain yang diuraiakan dalam spesifikasi desain RSG-GAS. Oleh karena itu, tujuan penelitian ini adalah untuk mendapatkan model penukar kalor semirip mungkin dengan program RELAP5/SCDAP/Mod3.4 code. Dari model yang dikembangkan, kinerja model penukar panas akan dievaluasi untuk mengetahui pengaruhnya terhadapt simulasi kondisi tunak selama daya penuh di RSG-GAS. Hasil simulasi menunjukkan bahwa kinerja model penukar panas yang telah diperoleh sesuai dengan spesifikasi desain untuk membuang panas teras selama simulasi daya penuh. Pada kondisi itu, penentuan temperatur inlet sisi sekunder dan koefisien hambatan aliran memegang peranan penting dalam penyesuaian nilai temperatur inlet dan outlet sisi primer untuk lebih sesuai dengan data eksperimen dan model RSG-GAS lainnya.

Kata kunci: RSG-GAS, model penukar panas, RELAP5, simulasi kondisi tunak, kinerja 


\section{INTRODUCTION}

Reactor G. A. Siwabessy (RSG-GAS) is a multipurposes research reactor located in the Puspiptek Area Serpong by design having thermal power of $30 \mathrm{MWt}$. It is a open pool, water cooled reactor with plate type fuel elements in the core. To remove the generated heat in the core, its cooling system consists of two parallel cooling lines, each equipped with one reactor cooling pump and one heat exchanger. Related to the reactor utilization, the RSG-GAS is currently operated with only $15 \mathrm{MWt}$ due to the budget savings since 1999 . The safety and reability of the reactor operation with decreased thermal power has been evaluated even with only one loop, in which only one reactor cooling pump and one heat exchanger are available [1]. The removal or transfer of generated heat from the core during normal operation have to be maintained all of the time to ensure the operational safety, especially to keep the fuel element temperature under prescribed operational limits ${ }^{[2]}$. On that case, two main components play an important role, which are the reactor cooling pump and heat exchanger. The reactor cooling pump will deliver a forced flow inside the primary loop and the heat exchanger will transfer the heat in the primary loop to the secondary system, and at the end the heat is removed to the environment. One method to assess the performance of RSG-GAS cooling system is by modelling the system using thermal hydraulic code such as RELAP5, which has been validated with the measurement data ${ }^{[3]}$. Modelling of RSG-GAS system has been performed several times by BATAN researcher, whether it is limited to the core only using COOLOD-N ${ }^{[4]}$ or as a complete system using RELAP5 ${ }^{[3,5]}$. Both RSG-GAS modelling using RELAP5 were basically generated from a similar model system, in which the fuel plate, fuel elements, the whole core, the pool vessel, piping system, delay chamber, reactor cooling pumps, and heat exchangers in two loop cooling system. The assessment of the RSG-GAS model was also reviewed as a whole system with the purpose to evaluate the calculated steady-state parameter during normal operation. An assessment of the accuracy of each main component as an individual such as reactor cooling pump and heat exchanger were not yet performed.

The purpose of this research is to make assessment on the performance of heat exchanger model of RSG-GAS generated using RELAP5/SCDAP/Mod3.4. The reason of this research is based on the review on the available input model, in which the heat exchanger was not fully modelled according to the technical specification described in the safety analysis report ${ }^{[2]}$. The model of heat exchanger was simply a combination of hydrodynamic components and heat structures, which enabled a heat transfer between primary and secondary cooling system to obtain determined operational parameters such as coolant temperature and pressure in the inlet and outlet. An exact model of heat exchanger based on the technical specifications is important to do in order to evaluate the capability of the code to model any thermal hydraulic characteristics arising from a heat exchanger compo- 
nent. The model will be then integrated with the whole RSG-GAS system model as nodal combination of various hydrodynamic components already obtained in the previous researches. The effect of the heat exchanger model will be analyzed in term of steady state operational parameter of the RSG-GAS using design data or experimental measurements.

\section{DESCRIPTION OF RSG-GAS HEAT EX-}

\section{CHANGER}

Heat exchanger (HE) component used in the RSG-GAS is a shell-and-tube type having advantage of bigger heat transfer surface area to enable better heat removal from primary system. There are two HEs in the RSG-GAS loop system, in which each is designed to remove heat of 16.5 MWt. Therefore those two are able to remove the generated core heat of $30 \mathrm{MWt}$. From physical point of view, the HE is a vertical component with counter current flow of hot primary side inside 2 shells and cold secondary side inside 2 tubes. Inside the $\mathrm{HE}$, there is a longitudinal baffle dividing the two vertical HE shells. The secondary coolant enters the tubes flowing downward via a canal head to flow upward leaving the HE and removing the heat from primary coolant inside the shells. Figure 1 illustrates the design of HE showing the flow directions and shell-and-tube design inside, while the design specification is summarized in Table 1.

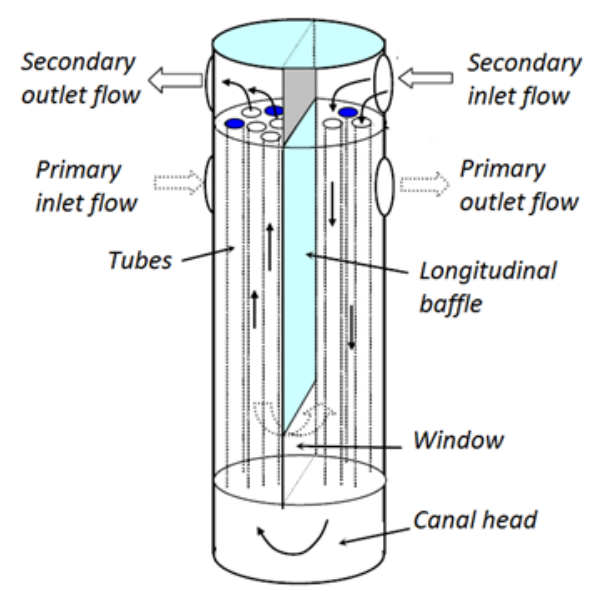

Figure 1. Design of RSG-GAS heat exchanger ${ }^{[6]}$

Table 1. Design specification of RSG-GAS heat exchanger ${ }^{[2,6]}$

\begin{tabular}{|l|l|}
\hline $\begin{array}{l}\text { Number of tubes on each } \\
\text { side }\end{array}$ & 816 \\
\hline Pitch tube / layout & $\begin{array}{l}1.25 \mathrm{~mm} / \\
\text { triangle }\end{array}$ \\
\hline Tube outside diameter & $23 \mathrm{~mm}$ \\
\hline Tube inside diameter & $22 \mathrm{~mm}$ \\
\hline Shell outside diameter & $1.300 \mathrm{~m}$ \\
\hline Shell inside diameter & $1.250 \mathrm{~m}$ \\
\hline Heat transfer area & $780 \mathrm{~m}{ }^{2}$ \\
\hline Height of tube & $7.410 \mathrm{~m}$ \\
\hline Shell pressure drop & $0.5 \mathrm{bar}$ \\
\hline Tube pressure drop & $0.4 \mathrm{bar}$ \\
\hline Total HE height & $9 \mathrm{~m}$ \\
\hline Design shell mass flow & $430 \mathrm{~kg} / \mathrm{second}$ \\
\hline Design tube mass flow & $485 \mathrm{~kg} / \mathrm{second}$ \\
\hline $\begin{array}{l}\text { T inlet / outlet primary } \\
\text { coolant }\end{array}$ & $\begin{array}{l}49-40^{\circ} \mathrm{C}(322 \\
-313 \mathrm{~K})\end{array}$ \\
\hline $\begin{array}{l}\text { T inlet / outlet secondary } \\
\text { coolant }\end{array}$ & $\begin{array}{l}32-40^{\circ} \mathrm{C}(305 \\
-313 \mathrm{~K})\end{array}$ \\
\hline
\end{tabular}


Data in Table 1 is utilized for modelling the HE component using the RELAP5. Important data to be used are diameter of tubes and shell to obtain hydrodynamic volumes forming the HE components and to define the coolant flows inside. The heat transfer between primary and secondary side is achieved by heat structure model, in which the heat transfer area and heat transfer mechanism shall be defined.

\section{MODELLING OF RSG-GAS HEAT EX- CHANGER}

Figure 2 shows the resulted modelling of HE using several hydrodynamic volumes as provided by the RELAP5 code. The RELAP5 model or volume nodalization simply consists of integration of several pipe components to represent the flow area and length geometry. The HE nodalization is divided into 2 parts representing the left and right side separation of the longitudinal baffle.

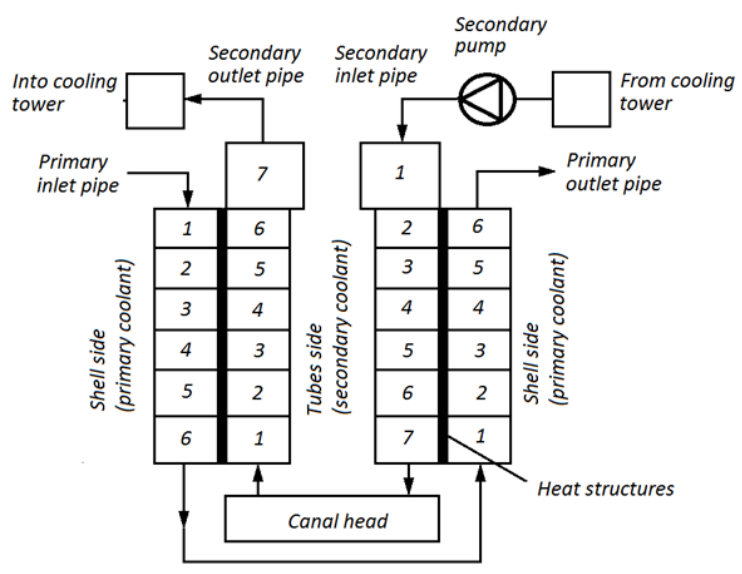

Figure 2. Nodalization of RSG-GAS heat exchanger using RELAP5 code
In the each shell side, the flow area is calculated from the half of HE shell area reduced by the total 816 tubes area to obtain $0.27452 \mathrm{~m}^{2}$ of shell area. The height of shell side is $7.41 \mathrm{~m}$ divided into 6 equally length segments. In the each tubes side, the flow area is calculated from 3 parts, which are the upper part connecting the inlet or outlet secondary pipe, the 816 tubes, and the canal head. The total area of 816 tubes is calculated as 0.3102 $\mathrm{m}^{2}$. The canal head is simply a single volume, in which the secondary flow upward is originated. The total height of the tubes side is arranged to obtain of designed HE height of 9 $\mathrm{m}$. The inlet and outlet volume of tubes side is connected to a time-dependent volume representing the boundary condition of cooling tower or outside environment. The determined boundary condition is $303 \mathrm{~K}\left(30^{\circ} \mathrm{C}\right)$ for inlet condition and $313 \mathrm{~K}\left(40{ }^{\circ} \mathrm{C}\right)$ for outlet condition with 1 bar atmospheric pressure. In the secondary inlet side, a time-dependent junction is attached to simulate a mass flow in the secondary line without pressure addition. The heat transfer between the shell side and tubes side is modelled as a heat structure connecting both volume. In the RELAP5, several input data shall be defined such as tube thickness, heat transfer surface area, and the values of thermal conductivity and heat capacity of HE material of X 10 CrNiTi 18 10.(DIN 1.4571). The result of heat transfer area obtained in the model is $783.57 \mathrm{~m}^{2}$ or not much deviated from the design specifications. From those inputs, the heat transfer coefficient and heat transfer rate can be calculated by defining the coolant 
mass flow. The generated model have to be attached into the rest of RSG-GAS model consisting of the core, pool vessel, piping system, delay chamber, and reactor cooling pumps to provide a boundary condition for testing the HE performance. The RSG-GAS system model to be attached is taken from available input data used in the previous research ${ }^{[5]}$.

\section{RESULTS AND DISCUSSION}

In order to evaluate the performance of HE model generated by the RELAP5 code, boundary conditions have to be defined, which are the generated heat or power in the core $\left(\mathrm{Q}_{c}\right)$, initial primary inlet temperature $\left(\mathrm{T}_{\mathrm{p} \text {-in }}\right)$, initial primary mass flow $\left(\mathrm{m}_{\mathrm{p}}\right)$, primary coolant pressure $\left(\mathrm{P}_{\mathrm{p}}\right)$ for the shell side and secondary inlet and outlet temperature $\left(\mathrm{T}_{\text {s-in }}, \mathrm{T}_{\mathrm{s} \text {-out }}\right)$ and secondary mass flow for the tubes side $\left(\mathrm{m}_{\mathrm{s}}\right)$. Those boundary condition parameters summarized in Table 2 are used for the first simulation.
Table 2. Input of boundary condition parameters for HE model simulation

\begin{tabular}{|l|l|}
\hline $\begin{array}{l}\text { Heat generated in the } \\
\text { core }\left(\mathrm{Q}_{\mathrm{c}}\right)\end{array}$ & $: 30 \mathrm{MW}$ \\
\hline $\begin{array}{l}\text { Primary inlet } \\
\text { temperature }\left(\mathrm{T}_{\mathrm{p} \text {-in }}\right)\end{array}$ & $: 315.94 \mathrm{~K}(42.94 \mathrm{C})$ \\
\hline $\begin{array}{l}\text { Primary inlet mass flow } \\
\left(\mathrm{m}_{\mathrm{p}}\right)\end{array}$ & $: 413.41 \mathrm{~kg} / \mathrm{sec}$ \\
\hline $\begin{array}{l}\text { Primary coolant } \\
\text { pressure }\left(\mathrm{P}_{\mathrm{p}}\right)\end{array}$ & $: 4.0259 \mathrm{bar}$ \\
\hline $\begin{array}{l}\text { Secondary inlet } \\
\text { temperature }\left(\mathrm{T}_{\mathrm{s} \text {-in }}\right)\end{array}$ & $: 303 \mathrm{~K}(30 \mathrm{C})$ \\
\hline $\begin{array}{l}\text { Secondary outlet } \\
\text { temperature }\left(\mathrm{T}_{\mathrm{s}-\text { out }}\right)\end{array}$ & $: 313 \mathrm{~K}(40 \mathrm{C})$ \\
\hline $\begin{array}{l}\text { Secondary inlet mass } \\
\text { flow }\left(\dot{\mathrm{m}}_{\mathrm{s}}\right)\end{array}$ & $: 540 \mathrm{~kg} / \mathrm{sec}$ \\
\hline
\end{tabular}

After 2000 seconds simulation following calculated parameters are obtained, which are heat generated to the secondary system $\left(\mathrm{Q}_{\mathrm{s}}\right)$, primary inlet temperature $\left(T_{p-i n}\right)$, primary outlet temperature $\left(\mathrm{T}_{\mathrm{p} \text {-out }}\right)$, primary outlet pressure $\left(\mathrm{P}_{\mathrm{p}}\right)$, and specific heat capacity $\left(\mathrm{c}_{\mathrm{p}}\right)$ estimated by the code as shown in the Table 3 for the first simulation.

Table 3. Results of steady-state simulation for RSG-GAS system parameter affected by the HE model

\begin{tabular}{|c|c|c|c|c|c|}
\hline Parameter & $1^{\text {nt }}$ imulation & $2^{\text {sd }}$ simulation ${ }^{\star}$ & 3rd simulation ${ }^{\star * t}$ & $\begin{array}{l}\text { Other RFI.AP5 } \\
\text { simulation }\end{array}$ & \begin{tabular}{|l} 
Measured \\
Data \\
\end{tabular} \\
\hline $\begin{array}{l}\text { Heat generated } \\
\text { in the core (Q.) } \\
\text { (MW) }\end{array}$ & 30.0 & 30.0 & 30.0 & 30.0 & 30.0 \\
\hline $\begin{array}{l}\text { Heat transferred } \\
\text { to secondary } \\
\text { system in one } \\
\mathrm{HE}\left(\mathrm{Q}_{4}\right)(\mathrm{MW})\end{array}$ & 15.19 & 15.02 & 15.18 & - & - \\
\hline $\mathrm{T}_{\mathrm{nin}}(\mathrm{K})$ & 317.64 & 322.25 & 317.75 & 322.62 & 321.03 \\
\hline$T_{\text {mava }}(\mathrm{K})$ & 308.74 & 313.44 & 308.72 & 312.72 & 312.75 \\
\hline$m_{\mathrm{g}-\mathrm{in}}(\mathrm{kg} / \mathrm{sec})$ & 406.56 & 406.27 & 400.99 & - & - \\
\hline$m_{\mathrm{g}-\mathrm{sa}}(\mathrm{kg} / \mathrm{sec})$ & 406.56 & 406.27 & 400.99 & - & - \\
\hline $\mathrm{P}_{\mathrm{a}-\mathrm{n}}(\mathrm{bar})$ & 2.30 & 2.30 & 2.39 & - & - \\
\hline $\mathrm{P}_{\mathrm{g}-\mathrm{sa}}(\mathrm{bar})$ & 2.12 & 2.12 & 2.09 & - & - \\
\hline$T_{2-n}(K)$ & 303.0 & 308.0 & 303.00 & 306.0 & 308.4 \\
\hline$T_{\text {acos }}(\mathrm{K})$ & 309.0 & 314.63 & 309.71 & 313.0 & 315.6 \\
\hline $\mathrm{P}_{\mathrm{a}<\mathrm{in}}(\mathrm{bar})$ & 1.33 & 1.33 & 1.52 & & \\
\hline $\mathrm{P}_{\mathrm{a}-\mathrm{wa}}$ (bar) & 1.13 & 1.13 & 1.13 & & \\
\hline$m_{k}(\mathrm{~kg} / \mathrm{gec})$ & 540.0 & 540.0 & 540.0 & - & - \\
\hline $\mathrm{c}_{\mathrm{s}}(\mathrm{J} / \mathrm{kgK})$ & 4178.4 & 4179.4 & 4178.4 & - & - \\
\hline
\end{tabular}

* increase of $\mathrm{T}_{\mathrm{s} \text {-in }}$ compared to $1^{\text {st }}$ calculation

** adding loss coefficient compared to $1^{\text {st }}$ calculation 
Those parameters are the results of the input parameters after passing through the HE model and achieving a steady-state or unchanged condition. On that condition, the primary inlet temperature defined as initial value may change during calculation according to the balance of heat generated in the core and heat transferred to the secondary system.

It shows from the 1st simulation that the heat removed by $1 \mathrm{HE}$ is around $15.19 \mathrm{MW}$ or 30.28 MW from 2 HEs, which results from additional heat generated in the reactor cooling pumps. Those heat removal decreases the inlet coolant temperature to $8.9 \mathrm{~K}$ before leaving the HE. The pressure inside the shells experiences a decrease of 0.18 bar and in the tubes of 0.2 bar, which is still below the design specifications and are caused by temperature decrease, not due to the friction inside the shell volume since coolant mass flow after and before entering the shell is constant. An emprical validation of the heat removal calculation $(\mathrm{Q})$ can be obtained from following equation ${ }^{[7]}$ :

$\mathrm{Q}=\dot{\mathrm{m}} . \mathrm{c}_{\mathrm{p}} \cdot\left(\mathrm{T}_{\mathrm{in}}-\mathrm{T}_{\text {out }}\right)$

Where:

$\dot{\mathrm{m}}=$ liquid mass flow $(\mathrm{kg} / \mathrm{sec})$

$c_{p}=$ liquid specific heat capacity $(\mathrm{J} / \mathrm{kg} . \mathrm{K})$

$\mathrm{T}_{\text {in }}, \mathrm{T}_{\text {out }}=$ inlet, outlet temperature $(\mathrm{K})$

In the primary side, $\dot{\mathrm{m}}$ is $406.56 \mathrm{~kg} / \mathrm{sec}, \mathrm{c}_{\mathrm{p}}$ is $4178.4 \mathrm{~J} / \mathrm{kg} . \mathrm{K}$, and primary temperature difference is $8.9 \mathrm{~K}$, which results in $\mathrm{Q}=15.13 \mathrm{MW}$ of heat removal. A similar result is obtained in the secondary side for heat absorption, in which the higher secondary mass flow results in lower secondary temperature difference.

An approximation of heat transfer rate through the tube walls $\left(\mathrm{Q}_{\text {wall }}\right)$ can be estimated using following general equation ${ }^{[7]}$ :

$\mathrm{Q}_{\text {wall }}=\mathrm{k}_{\mathrm{a}} \times \mathrm{A}_{\mathrm{a}} \times \Delta \mathrm{T}_{\mathrm{m}}$

Where

$\mathrm{k}_{\mathrm{a}}=$ overall heat transfer coefficient

$\mathrm{A}_{\mathrm{a}}=$ outside tube wall area

$\Delta \mathrm{T}_{\mathrm{m}}=\log$-mean temperature difference

Since the flow inside HE is a countercurrent flow, the $\Delta \mathrm{T}_{\mathrm{m}}$ can be calculated by following equation ${ }^{[7]}$ :

$\Delta T_{m}=\frac{\left(T_{p-\text { out }}-T_{s-\text { in }}\right)-\left(T_{p-\text { in }}-T_{s-\text { out }}\right)}{\ln \frac{\left(T_{p-\text { out }}-T_{s-\text { in }}\right)}{\left(T_{p-\text { in }}-T_{s-\text { out }}\right)}}$

By using the data in Table 3 and from the RELAP5 data output, $\Delta \mathrm{T}_{\mathrm{m}}$ is calculated to be 7.09144 and $A_{a}$ is $800.58 \mathrm{~m}^{2}$. The overall heat transfer coefficient $k_{a}$ is calculated from the convective heat transfer coefficient inside and outside the tubes, tube thickness, and heat conductivity of the tube material, which also can be obtained from the RELAP5 data output. The results of $k_{a}$ is around $3095.96 \mathrm{~W} /$ $\mathrm{m}^{2} . \mathrm{K}$, therefore the $\mathrm{Q}_{\text {wall }}$ is calculated to be 17.57 MW, which is close with the RELAP5 calculation. The deviation from the $15 \mathrm{MW}$ is due to the selection of the convective heat transfer coefficient inside and outside the tubes, since the formula is for approximation purposes only. 
The secondary inlet temperature may experience an increase due to the effectivity of the cooling tower or increase on the environment air temperature. An assumption of secondary inlet temperature increase is made to $308 \mathrm{~K}$ for the $2^{\text {nd }}$ simulation. The results showed in Table 3 indicate an increase in the primary inlet temperature due to the decrease of HE heat removal to $322.25 \mathrm{~K}$ or $4.61 \mathrm{~K}$ higher. It shows that an increase in the environment air temperature will affect the HE capability to remove the heat from the primary side, therefore the secondary pump must also increase its mass flow rate.

The model of HE is developed without the effect of flow resistance inside the shell and tube volume since there are an abrupt direction from the downward inlet flow to the upward outlet flow. To estimate the effect of the flow resistance inside the HE, a loss coefficient of 10.01 and 6.01 is added in the input data, which is located in the bottom of each shell and tube section respectively. The results of calculation with the additional loss coefficient is summarized in the $3^{\text {rd }}$ simulation of Table 3 . It shows that an additional loss coefficient will decrease the mass flow flowing through the shell volumes but not in the tube volumes but the pressure differences between the inlet and outlet side are increased to be close with the design specifications. The addional loss coefficient does not affect the heat removal capability of the heat exchanger and therefore the inlet and outlet temperature in the primary side. Compared with the experimental data ${ }^{[8]}$ and other RSG-GAS model generated by other resear- cher ${ }^{[9]}$, the value of the secondary inlet temperature plays significant role in taking the parameter of inlet and outlet primary temperature to be close with the data as summarized in the $2^{\text {nd }}$ simulation. In general, the obtained heat exchanger model can be used with the overall RSG-GAS system model for the simulation in normal operation or accident condition.

\section{CONCLUSION}

The model of heat exchanger in the RSG-GAS reactor has been obtained by RELAP5/SCDAP/Mod3.4. The model has been validated for its performance during a steadystate simulation to remove the core heat with the $30 \mathrm{MWt}$ full power with the design specification, in which some basic calculation has been verified by empirical approximation. On that condition, the inlet secondary temperature and loss coefficient plays important role in taking the inlet and outlet primary temperature to be close with the experimental data and other RSG-GAS model. In general, the obtained heat exchanger model can be used with the overall RSG-GAS system model for the simulation in normal operation or accident condition.

\section{ACKNOWLEDGEMENT}

This work was fully funded by BATAN research project (DIPA) of the year 2017, which was managed by Center for $\mathrm{Nu}$ clear Reactor Safety and Technology (PTKRN). The author is very thanksful to the Center for Multipurpose Reactor for providing 
necessary document for comparison purposes.

\section{REFERENCES}

1. M. D. Isnaini, Y. Murayama, "Evaluasi Termohidrolika Kondisi Tunak Teras RSG-GAS Pada Operasi Daya 15 MWt Dengan 1 Pompa Pendingin Primer, Proceeding Pertemuan dan Presentasi Ilmiah, PPNY-BATAN, Yogyakarta $14-15$ Juli 1999.

2. BATAN. Laporan Analisis Keselamatan (LAK) RSG-GAS Rev. 10.1. Badan Tenaga Nuklir Nasional; December 2011. Dokumen No. RSG.KK.01.63.11.

3. S. Dibyo, Tri Dasa Mega 7(2) (2005).

4. E. P. Hastuti, M. Kaminaga, "Analisis Kecelakaan Penyumbatan Parsial Kanal Pendingin Elemen Bakar Pada Teras Oksida dan Disain Teras Silisida RSGGAS”, Proceeding Pertemuan dan Presentasi Ilmiah PPNY-BATAN, Yogyakarta 14 - 15 Juli 1999.

5. A. S. Ekariansyah, Susyadi, S. Dibyo, Tri Dasa Mega 8 (3), 114 - 125 (2006).

6. Djunaidi, A. S. Catur, Syafrul, "Evaluasi Kinerja Alat Penukar Panas RSG-GAS Pasca Inspeksi", Buletin Pengelolaan Reaktor Nuklir. 7 (2), 32 - 38 (2010) (in Indonesian).

7. W. Wagner, "Warmeaustaucher: Grundlagen, Ausbau und Funktion thermischer Apparate, 1. Aufl. - Wurzburg: Voegel 1993 [in German].

8. I.D. Abdelrazek, M. Naguib Aly, A.A. Badawi, A.G. Abo Elnour, Annals of Nuclear Energy (70), 36-43 (2014).
9. S. Chatzidiakis, A. Hainoun, A. Doval, F. Alhabet, A. Francioni, A. Ikonomopoulos, D. Ridikas, Nuclear Engineering and Design 268, 77- 86 (2014). 